\title{
Bivalve fauna and distribution in the Amur River estuary - a warm-water ecosystem in the cold-water Pacific region
}

\author{
Gennady M. Kamenev*, Dmitry A. Nekrasov \\ A.V. Zhirmunsky Institute of Marine Biology of the Far Eastern Branch of the Russian Academy of Sciences, \\ Palchevskogo St., 17, Vladivostok 690059, Russia
}

\begin{abstract}
The understanding of the processes regulating the species richness and diversity in estuarine ecosystems is a fundamental problem of ecology. The Amur River estuary is characterised by high summer water temperatures (up to $20-21^{\circ} \mathrm{C}$ ) anomalous for the cold-water northwestern Pacific region. We hypothesized that the warm-water Amur estuary greatly influences the species richness of this cold-water region, contributing to the far northward spread of warm-water macrobenthic species. We investigated the fauna and distribution of bivalves in relation to environmental variables in the Amur estuary (Sakhalin Gulf, Amurskiy Liman, and northern Tatar Strait) on the basis of samples collected during 6 expeditions between 2003 and 2007. Most of the bivalve species found in the estuary (30 of 41) are marine species, which were recorded only in Sakhalin Gulf (Sea of Okhotsk) and the Tatar Strait (Sea of Japan). In the greater part of Amurskiy Liman, we found only brackish-water species Corbicula japonica, Corbula amurensis, and Macoma balthica, which were most abundant (mean \pm SE: $74.6 \pm 3.4 \%$ of the total biomass per station) among the macrobenthos. Qualitative (presence/absence of species) and quantitative (fourth-root transformed biomass) cluster and multidimensional scaling analyses revealed 6 distinct areas in the estuary. Depth, temperature, and salinity of the bottom water and sediment characteristics (clay content) exert the greatest effect on the distribution of bivalves in the estuary. The environmental conditions in the warm-water Amur estuary are favourable for the reproduction and existence of the warm-water species C. japonica, C. amurensis, Venerupis philippinarum, Crassostrea gigas, Raeta pulchella, Protothaca euglypta, and Callithaca adamsi, of which $C$. japonica and $C$. amurensis determine the bottom community structure and abundance in the oligohaline and mesohaline zones of the estuary. The Amur estuary is the northern distribution limit of natural populations of these species and serves the role of a refugium for many warmwater species of the northwestern Pacific.
\end{abstract}

KEY WORDS: Bivalve molluscs - Distribution - Abundance - Environmental conditions · Amur River estuary

Resale or republication not permitted without written consent of the publisher

\section{INTRODUCTION}

Estuaries provide many important ecosystem functions, including high biological production, nursery and feeding habitats for epibenthic fish, crustaceans and birds, and other services, such as pollution filtration and shoreline stabilization (Herman et al. 1999,
McLusky \& Elliott 2004). Estuaries are also among the most extensively modified ecosystems, threatened largely by human activities (Wolanski 2007). In most estuaries, macrobenthic invertebrates are important in structuring communities, food webs, ecosystem dynamics, and often play a key role in monitoring programs designed to detect ecosystem change, for ex- 
ample, those related to climate change (Day et al. 1989, Engle \& Summers 1999, Wijnhoven \& Hummel 2011). As such, examining the spatial distribution of benthic invertebrates as they vary with environmental conditions, human perturbations, and natural disturbances is fundamental to the study of marine and estuarine ecology in a rapidly changing world. Knowledge of the spatial distribution of macrobenthos along estuarine gradients might help to identify the linkages between species distributions and ecological processes and therefore to gain insight into the functioning of estuarine ecosystems (Herman et al. 1999, Ysebaert et al. 2003, McLusky \& Elliott 2004).

It is well known that the local-scale distribution of estuarine benthic invertebrates is determined mainly by salinity, sediment type, oxygen content, and water depth (Ysebaert \& Herman 2002, Ysebaert et al. 2003, Kraufvelin et al. 2011), whereas the species distribution on a large geographical scale correlates primarily with water temperature (Kafanov 1991, Roy et al. 1998, Engle \& Summers 1999, Gray 2002). Undoubtedly, at small spatial scales water temperature along with many local environmental variables (water current, sedimentation, eutrophication, etc.) may also affect the distribution of macrobenthic organisms in an estuary (Kraufvelin et al. 2011, Beseres Pollack et al. 2011). However, the overriding influence of water temperature on the species composition, distribution and structure of benthic communities on a local scale in estuarine ecosystems have been poorly studied due to the absence of an appropriate model system with sharp temperature gradient. The little-studied Amur estuary (Ushakov 1934, 1940, 1948, Labay 2004) can provide such a model ecosystem to test the assumption that water temperature under certain conditions may also be one of the main factors determining the distribution of estuarine benthic invertebrates. Firstly, the Amur River flows from south to north, and, in summer, transports significant masses of warm water (20 to $21^{\circ} \mathrm{C}$ ) to the estuary and the adjacent northern coldwater $\left(6\right.$ to $\left.8^{\circ} \mathrm{C}\right)$ region of the northwestern Pacific (Ushakov 1953, Plotnikov 2007). The Amur River is one of the world's 10 longest rivers $(4444 \mathrm{~km})$ with a watershed of $1855000 \mathrm{~km}^{2}$ (Lizova 2007). The average annual discharge from the Amur River is $370 \mathrm{~km}^{3}$, which makes up $65 \%$ of the total river discharge to the Sea of Okhotsk (Zhabin et al. 2007). About $87 \%$ of the annual river discharge occurs in the warm season (May to October) (Dudarev et al. 2000). Therefore, the Amur estuary is characterized by high summer water temperatures, which are anomalous for these latitudes. Secondly, the river flow is discharged to the north and south of Sakhalin Island at the river mouth into the warm-water Sea of Japan (average annual water temperature is 13 to $14^{\circ} \mathrm{C}$ ) and the cold Sea of Okhotsk (average annual water temperature is 3 to $4^{\circ} \mathrm{C}$ ) (Luchin 2007, Plotnikov 2007). Thus, the Amur estuary is influenced by waters originating from the river and the seas of Japan and Okhotsk and hence has a complex hydrological and hydrochemical regime with high gradients of many parameters. Thirdly, like Arctic estuaries, the Amur estuary is long covered by a thick ice during the winter-spring season (6 to $7 \mathrm{mo}$ ).

The Amur estuary is considered a major biogeographical boundary separating relatively warmwater and cold-water marine faunas of the northwestern Pacific (reviewed by Kafanov 1991). The main criterion of demarcation is the northern distribution limits of warm-water families of marine organisms. Many investigators showed that certain representatives of warm-water families inhabit the northern Sea of Japan to the south of the estuary, but they are absent in the Sea of Okhotsk to the north of the estuary. Nevertheless, some warm-water species of fauna and flora have been previously recorded in the Amur estuary (Ushakov 1948, 1953, Scarlato 1981, Labay 2004). However, the influence of the estuary on the species richness, diversity, and distribution of the fauna in this boundary region between the Sea of Japan and the Sea of Okhotsk is uncertain. Taking into account that the relatively high summer water temperature in the estuary may create favourable conditions for the existence of warm-water fauna, we hypothesize that the transport of warm river water into the estuary in summer, as well as the geographical position and specific geomorphological features of the estuary, contribute to the northward spread of warm-water species of macrobenthos and their establishment among the fauna of one of the coldest-water regions of the northwestern Pacific.

Bivalves are a widely distributed, often dominant (in terms of abundance), and low-mobility group of macrobenthos in estuaries and a variety of marine habitats. They can be highly responsive to local human activities, as well as to either long-term or largescale climatic changes (Scarlato 1981, Kafanov 1991, Coan et al. 2000, Valentine \& Jablonski 2010), and have been proposed as possible surrogates for the study of the distribution and diversity of the whole macrobenthic community (Anderson et al. 2005). Previous studies showed that bivalves are the most abundant group of benthic animals in the Amur estuary (Dulenina 2003, Labay 2004). Thus, we believe that they provide appropriate organisms to test our 
starting hypothesis outlined in the previous paragraph. With the aim of verifying this hypothesis, the present study focuses on the following objectives: to examine the species composition of bivalves of the Amur estuary; to investigate the spatial and quantitative distributions of bivalves in the estuary; to identify areas within the estuary differing in the species composition of bivalves; and to determine environmental factors influencing the distribution of bivalves.

\section{MATERIALS AND METHODS}

\section{Study area}

The Amur estuary extends south to north for more than $300 \mathrm{~km}$. It includes Amurskiy Liman (a strait connecting the Sea of Japan and Sea of Okhotsk), Sakhalin Gulf (Sea of Okhotsk), and the northern Tatar Strait (Sea of Japan) to about $50 \mathrm{~m}$ deep (Zhabin et al. 2007) (Fig. 1a). The Amur River flow enters a longitudinally extended Amurskiy Liman, which forms the major portion of the estuary. The southern border of Amurskiy Liman runs along a line connecting Cape Yuznhy and Cape Tyk, Sakhalin Island. Its northern border is a line extending from Cape Menshikov to Cape Tamlavo, Sakhalin Island. Amurskiy Liman is $190 \mathrm{~km}$ long, $4205 \mathrm{~km}^{2}$, and water depths range from 1 to $5 \mathrm{~m}$. There are 4 narrow winding ship channels up to $20 \mathrm{~m}$ deep (Fig. 1b), which ensure navigation and main exchange of water with adjacent areas of the Seas of Japan and Okhotsk (Starkov 2003, Zhabin et al. 2007, 2009).

In summer, anomalously warm river waters (up to 20 to $21^{\circ} \mathrm{C}$ ) enter the estuary. Up to $67 \%$ of the river flow at the ice-free period is discharged through Amurskiy Liman into Sakhalin Gulf (Sea of Okhotsk), where under the Coriolis effect the river water is being pushed toward the northwestern coast of Sakhalin Island and transported up to its northeastern coast (Fig. 1c). Here, warm and freshened water from Amurskiy Liman forms a discharge plume 5 to $10 \mathrm{~m}$ thick with a water temperature of 12 to $15^{\circ} \mathrm{C}$ and a salinity of 5 to $15 \mathrm{psu}$. The temperature of water near the bottom, at depths greater than $10 \mathrm{~m}$, in Sakhalin Gulf at this period is $-1.75^{\circ} \mathrm{C}$ to $0.1^{\circ} \mathrm{C}$, with a salinity above 33 psu (Zhabin et al. 2007, 2009). The remaining volume of river water enters the Tatar Strait (Sea of Japan). In winter, the scheme of water exchange is the opposite (Dudarev et al. 2000). Moreover, in summer very cold (to $-1.8^{\circ} \mathrm{C}$ ) water from the Sea of Okhotsk, as well as warmer water from the Sea of Japan comes into Amurskiy
Liman at high tide (Zhabin et al. 2009). In summer, near the Amur River mouth, the salinity of nearbottom water is the lowest ( 0.04 to $5 \mathrm{psu})$, with a temperature of 16 to $19^{\circ} \mathrm{C}$. In northern Amurskiy Liman, the salinity of the near-bottom layer is 10 to $16 \mathrm{psu}$ and the temperature 7 to $8^{\circ} \mathrm{C}$. In southern Amurskiy Liman, the salinity of the near-bottom water increases to 25 to $30 \mathrm{psu}$, with a temperature of 10 to $13^{\circ} \mathrm{C}$ (Zhabin et al. 2007, 2009). The first ice in Amurskiy Liman appears in late October to early November, and the estuary is usually ice-free by June through October. Ice cover is on an average $1 \mathrm{~m}$ thick and the greater part of Amurskiy Liman freezes through to its bottom. The area of contact of bottom and ice is $2900 \mathrm{~km}^{2}$ (Dudarev et al. 2000, Starkov 2003, Zhabin et al. 2009).

\section{Sample collection}

Macrobenthos was sampled in summer during 6 expeditions between 2003 and 2007 (Table 1). To examine the species composition and distribution of bivalves in the estuary, sampling was carried out throughout the Amur estuary. The sampling design, although slightly unbalanced, covered 3 different areas of the Amur River estuary: the relatively warmwater and deep northern part of the Tatar Strait (Sea of Japan); the warm-water and shallow strait Amurskiy Liman that connects the Seas of Japan and Okhotsk; and the cold-water and deep Sakhalin Gulf (Sea of Okhotsk) (Fig. 1a). In the southern and northern estuary where there is the most active discharge of estuarine waters from Amurskiy Liman into the Seas of Japan and Okhotsk, the grid of stations was denser in order to follow the change of hydrochemical characteristics of water and the species composition and richness of bottom fauna. At great depths of Sakhalin Gulf, Tatar Strait and ship channels with sandy and silty sand sediments (Fig. 1d), macrobenthic invertebrates were sampled with large and heavy 'Okean' $\left(0.25 \mathrm{~m}^{2}\right)$ and van Veen $\left(0.2 \mathrm{~m}^{2}\right)$ grabs. In shallow-water areas of the estuary with silts, we used smaller van Veen $\left(0.1 \mathrm{~m}^{2}\right)$ and Peterson $\left(0.034 \mathrm{~m}^{2}\right)$ grabs, which also allow sampling of deeply-burrowing macrobenthic invertabrates (Ysebaert \& Herman 2002). A total of 155 stations were performed at depths from 1.5 to $54 \mathrm{~m}$. In order to reduce the influence of small-scale spatial variability at station, 3 replicate samples were collected at each station.

All samples were washed over $1 \mathrm{~mm}$ mesh sieves. The retained macrobenthic animals were fixed in $4 \%$ buffered formalin for later identification and enumer- 


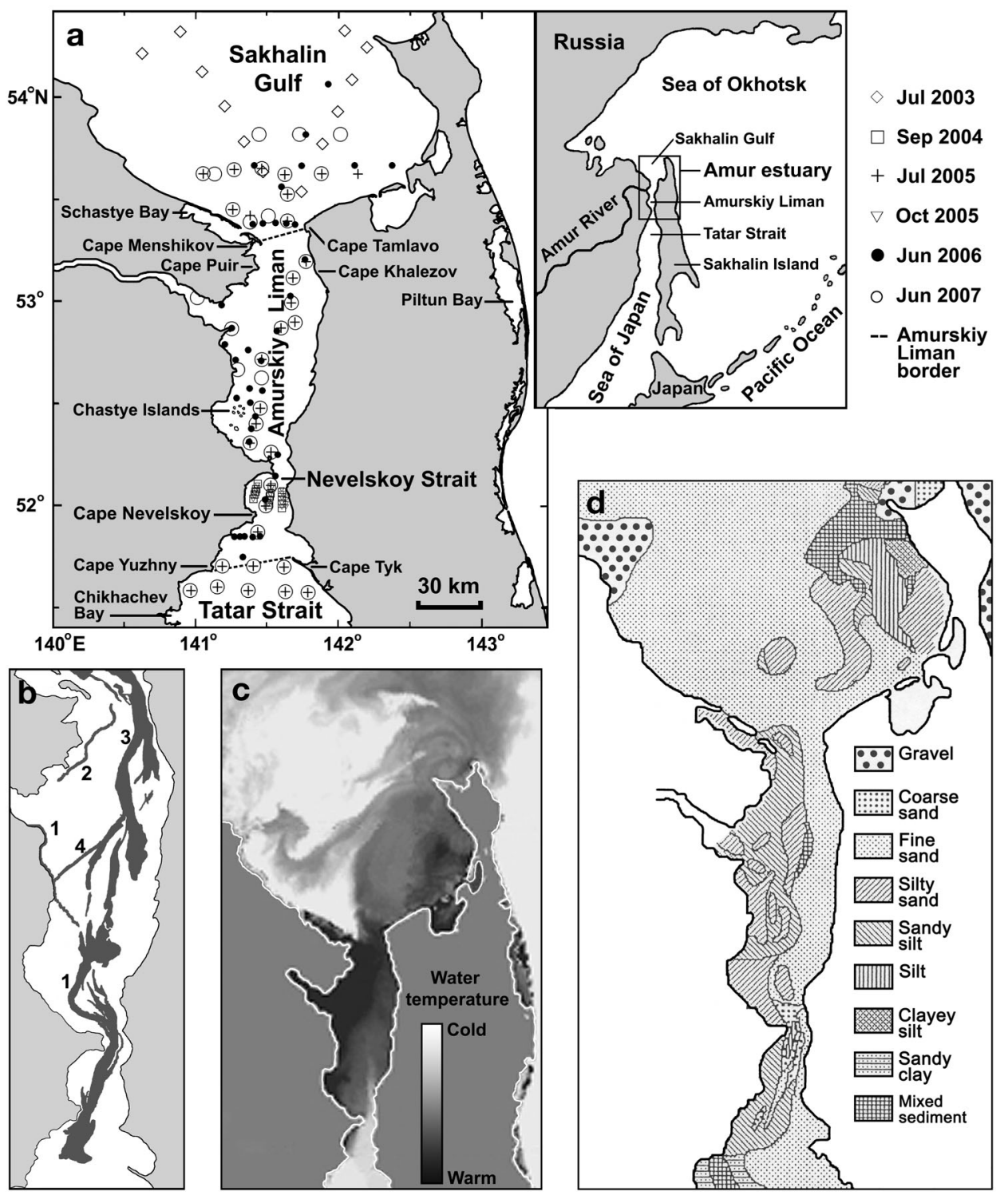

Fig. 1. Map of the Amur River estuary: (a) location of the sampling stations; (b) position of ship channels (1-4) in Amurskiy Liman (from Zhabin et al. 2007); (c) surface temperature $\left({ }^{\circ} \mathrm{C}\right.$ ) distribution on July 11, 2005 based on NOAA satellite data (from Zhabin et al. 2007); (d) distribution of bottom sediments (from Dudarev et al. 2000)

ation in the laboratory. In the laboratory, bivalves were separated from the remaining species, identified, counted and weighed with their shells for formalin wet weight. Formalin wet weight (wet wt) was used as the biomass indicator because the drying of the specimens would have resulted in an undesired loss of valuable taxonomic material. The use of formalin wet weight also enables the comparison of the results with previously published data (e.g. Labay 2004, Dulenina \& Dulenin 2009). The species names of bivalve molluscs and taxonomic affiliations are consistent with Coan et al. (2000), Coan (2002) and Kantor \& Sysoev (2005).
In order to determine environmental factors influencing the distribution of bivalves, we examined the hydrochemical parameters of the water and the sediment characteristics at stations. The following environmental variables were used in the analyses of mollusc samples: depth, temperature $\left({ }^{\circ} \mathrm{C}\right)$ and salinity (psu) of the water near the bottom, concentration of $\mathrm{O}_{2}\left(\mathrm{ml} \mathrm{l}^{-1}\right), \mathrm{PO}_{4}\left(\mu \mathrm{M} \mathrm{l}^{-1}\right), \mathrm{SiO}_{3}\left(\mu \mathrm{M} \mathrm{l}^{-1}\right), \mathrm{NH}_{4}(\mu \mathrm{M}$ $\left.\mathrm{l}^{-1}\right), \mathrm{NO}_{3}\left(\mu \mathrm{M} \mathrm{l}^{-1}\right)$ in the water near the bottom, percentage of gravel sand, silt and clay in sediments. CTD probe (SBE 19 plus) measurements of temperature, salinity, and oxygen concentration were made during the July 2003, July 2005, June 2006, and June 
Table 1. Number of hydrobiological stations sampled in the different geographical areas of the Amur River estuary on 6 expeditions, with indications of investigated depths and the sampling grabs used. -: research was not conducted

\begin{tabular}{|c|c|c|c|c|c|c|c|c|}
\hline \multirow[t]{2}{*}{$\begin{array}{l}\text { Sampling } \\
\text { date }\end{array}$} & \multicolumn{2}{|c|}{$\begin{array}{c}\text { Northern } \\
\text { Tatar Strait } \\
\text { (Sea of Japan) }\end{array}$} & \multicolumn{2}{|c|}{$\begin{array}{l}\text { Amurskiy } \\
\text { Liman }\end{array}$} & \multicolumn{2}{|c|}{$\begin{array}{c}\text { Sakhalin } \\
\text { Gulf } \\
\text { (Sea of Okhotsk) }\end{array}$} & \multirow[t]{2}{*}{$\begin{array}{l}\text { Sampling grab } \\
(\text { sampled area } \\
\text { in } \mathrm{m}^{2} \text { ) }\end{array}$} & \multirow[t]{2}{*}{ Expedition } \\
\hline & $\begin{array}{c}\text { No. of } \\
\text { stations }\end{array}$ & $\begin{array}{l}\text { Depth } \\
(\mathrm{m})\end{array}$ & $\begin{array}{l}\text { No. of } \\
\text { stations }\end{array}$ & $\begin{array}{l}\text { Depth } \\
(\mathrm{m})\end{array}$ & $\begin{array}{l}\text { No. of } \\
\text { stations }\end{array}$ & $\begin{array}{l}\text { Depth } \\
(\mathrm{m})\end{array}$ & & \\
\hline Jul 2003 & - & - & - & - & 12 & $3-54$ & Okean (0.25) & $\begin{array}{l}\text { Institute of Marine Biology (IMB), } \\
\text { Pacific Oceanological Institute (POI), } \\
\text { Pacific Institute of Bioorganic Chemistry } \\
\text { (PIBOC) (RV 'Akademik Oparin') }\end{array}$ \\
\hline Sep 2004 & - & - & 15 & $1.5-18$ & - & - & $\begin{array}{l}\text { van Veen }(0.2) \\
\text { Petersen }(0.034)\end{array}$ & $\begin{array}{l}\text { Sakhalin Ecological Company (SEC) } \\
\text { (oil pipeline area in Nevelskoy Strait) }\end{array}$ \\
\hline Jul 2005 & 8 & $10-24$ & 13 & $6-17$ & 10 & $10-24$ & van Veen $(0.1)$ & IMB-POI (RV ‘Professor Gagarinsky') \\
\hline Oct 2005 & - & - & 21 & $2-17$ & - & - & Petersen (0.034) & SEC (oil pipeline area in Nevelskoy Strait) \\
\hline Jun 2006 & - & - & 25 & $3-17$ & 12 & $7-49$ & van Veen $(0.1)$ & $\begin{array}{l}\text { IMB-POI ('BGK-795' and 'BGK-682', } \\
\text { RV 'Professor Gagarinsky') }\end{array}$ \\
\hline Jun 2007 & 8 & $9-24$ & 17 & $6-19$ & 14 & $9-24$ & van Veen $(0.1)$ & IMB-POI (RV ‘Professor Gagarinsky’) \\
\hline Total & 16 & $9-24$ & 91 & $1.5-19$ & 48 & $7-54$ & - & - \\
\hline
\end{tabular}

2007 expeditions (Table 1) at each station. Water samples were also taken near bottom at each station using a 51 Niskin bottle. Oxygen probe data were regularly calibrated with Winkler titration. Concentrations of nutrients were measured using a photoelectric calorimeter. Sediment cores (diameter $5 \mathrm{~cm}$ ) were taken to a depth of $10 \mathrm{~cm}$ (0 to $10 \mathrm{~cm}$ fraction) at each station during the June 2006 and June 2007 expeditions for sediment analysis. Sediment samples were analysed by sieve analysis and laser scanning of suspension (Analysette 22 FRITCH). The hydrochemical characteristics of the water column and the sediment grain size data were provided by Drs. O. V. Dudarev, A. I. Botsul and I. A. Zhabin (V.I. Il'ichev Pacific Oceanological Institute, Vladivostok).

\section{Data analysis}

Before statistical data treatment, the total number of species was calculated for each station based on the sum of the 3 replicates in order to evaluate the species richness and compare the species composition of different regions of the estuary. To examine the quantitative distribution of bivalves in the estuary, the characterization of each species was done according to the species abundance (biomass and density) and the frequency index (percentage of samples in which the species is present). Since macrobenthos samples were collected using grabs of different sampling area, all the data were recalculated into densities (ind. $\mathrm{m}^{-2}$ ) and biomass ( $\mathrm{g}$ wet $\mathrm{wt}$ $\mathrm{m}^{-2}$ ) at the species level.
Cluster and multidimensional scaling (MDS) analyses were chosen to identify areas in the estuary differing in the species composition of bivalves and to investigate the bivalve assemblage structure. Hierarchical clustering (using group-average linking) of all stations from the Amur estuary based on the BrayCurtis similarity measure was used to detect bivalve assemblages. The similarity index of Bray and Curtis (1957) was used as a meaningful and robust measure (Clarke 1993). The similarity of the molluscan assemblages of each station was measured using both qualitative data (presence/absence) and quantitative data (fourth-root transformed biomass) of species contained in each station (the replicate quantitative data were averaged within stations). Because the values for biomass and density of bivalve species in the Amur estuary span several orders of magnitude, these quantitative data were fourth-root transformed prior to multivariate analysis (Clarke \& Warwick 2001). Soft-sediment communities often consist of relatively high fractions of rare species compared with other environments (Gray et al. 2005). Community structure is not driven exclusively by dominant species, and rare species are also important (Kraufvelin et al. 2011). Many rare species were found, but extremely rarely and in the different sampling years. Consequently, for multidimensional analysis, the data for all years of study were pooled in order to include all rare species. Cluster analysis was conducted using the similarity matrix to produce the dendrograms. MDS was performed to produce the ordination plots. Formal significance tests for differences between groups of stations were addressed 
using 1-way ANOSIM tests. ANOSIM's statistic R estimates the difference between average rank similarities among pairs of replicates within each of 2 groups and the average rank similarity of replicates between groups. The SIMPER procedure (similarity percentage routine) was used to identify the level of within-group sample dissimilarity (or similarity) and the particular species responsible for the differences between groups (Clarke 1993). The relations between the biological (species abundance) and environmental data were investigated using the BIOENV analysis (Clarke \& Ainsworth 1993) and Spearman's rank correlation (Sokal \& Rohlf 1995). The RELATE test was applied to determine the significance of any relationships between the similarity matrices (based on Bray-Curtis similarity) underlying the biological and environmental data. The BIOENV procedure was used to identify which of the tested environmental variables best explained the observed patterns in mollusc distribution (Clarke \& Gorley 2001). This was achieved by selecting subsets of the available variables that maximized the rank correlations between the 2 matrices. Univariate analyses were performed using the StatSoft's STATISTICA 5.0 (Hill \& Lewicki 2006). Multivariate analyses were performed using the Plymouth Routines In Multivariate Ecological Research (PRIMER) package, v5 (Clarke \& Gorley 2001). Maps of spatial distributions of bivalves biomass and density were made using SURFER 8 (Golden Software 2002).

\section{RESULTS}

\section{Species composition and structure of bivalve fauna}

In the region studied, we found 41 species of bivalves (Table $\mathrm{S} 1$ in the supplement at www.intres.com/articles/suppl/m455p195_supp.pdf). Most of them (30 species) were found in Sakhalin Gulf (Sea of Okhotsk). Thirteen were recorded in the northern Tatar Strait (Sea of Japan). Eleven species were found in Amurskiy Liman, of which Raeta pulchella, Ennucula tenuis, Crassostrea gigas, Venerupis philippinarum and Siliqua alta were recorded in the very south near the conditional boundary with the Tatar Strait, while small freshwater species Henslowiana sp. and Pisidium orientale were only found in the Amur River mouth. Warm-water species comprised $17.1 \%$ of the total bivalve fauna of the Amur estuary. All of them were found only in the northern Tatar Strait and Amurskiy Liman, constituting one-third of the total bivalve fauna in these areas.
Bivalve molluscs were found at almost all stations in the different areas of the Amur estuary (frequency index $88.7 \%$ ) (Table S1). The proportion of bivalves in the total macrobenthos biomass at stations in the Tatar Strait and Sakhalin Gulf did not on average exceed $30 \%$. In Amurskiy Liman, the average contribution of bivalves to the total macrobenthos biomass was markedly higher (mean \pm SE: $74.6 \pm 3.4 \%$ ). The greatest abundance of bivalves was also observed in Amurskiy Liman, where they are the dominant group of macrobenthos with a biomass of up to $600 \mathrm{~g}$ wet wt $\mathrm{m}^{-2}$ and a population density of more than 800 ind. $\mathrm{m}^{-2}$ (Fig 2, Table S2 in the supplement).

The cluster and MDS analyses of the qualitative and quantitative data defined 6 main groups of stations (Fig. 3): (1) Tatar Strait, stations sampled in southern Amurskiy Liman and the northern Tatar Strait (T); (2) Sakhalin Gulf (S); (3) mouth of river (MR); (4) Amurskiy Liman (L); (5) exit to Sakhalin Gulf (ES); (6) exit to Tatar Strait (ET). The molluscan species composition and structure in these groups of stations are significantly different according to ANOSIM analyses (Global $\mathrm{R}=0.617, \mathrm{p}<0.001$ ). The ANOSIM test indicated that the differences between stations that were carried out in different years were not significant within the groups (R-statistics varied from -0.286 to 0.356 , p-values from 0.08 to 100 ). No shared species of bivalves were found between the marine parts of the estuary (areas S and T) and the highly freshened main part of Amurskiy Liman (areas MR, L, ES, ET) (Fig. 3). The areas $\mathrm{S}$ and T had a typically marine bivalve fauna (Table S1). The fauna of Amurskiy Liman is markedly impoverished and is mostly represented by only 3 brackish-water species: Corbicula japonica, Corbula amurensis and Macoma balthica. With a decrease in species richness, the proportion of warm-water species in bivalve composition and total macrobenthos biomass increased from the south (area T) to the north towards the central estuary (areas L and MR) (Fig. 4). In the central estuary, the bivalve fauna was represented only by warm-water species, which entirely dominated the macrobenthic communities (up to $99 \%$ of the total macrobenthos biomass at station). In the northern estuary (area S), warm-water species were not found.

\section{Characterization of the areas distinguished in the estuary and bivalve assemblages}

In the southern estuary (area T) with an average near-bottom temperature of water $7.9 \pm 0.9^{\circ} \mathrm{C}$ (mean \pm SE) and slightly decreased salinity $(30.7 \pm$ 

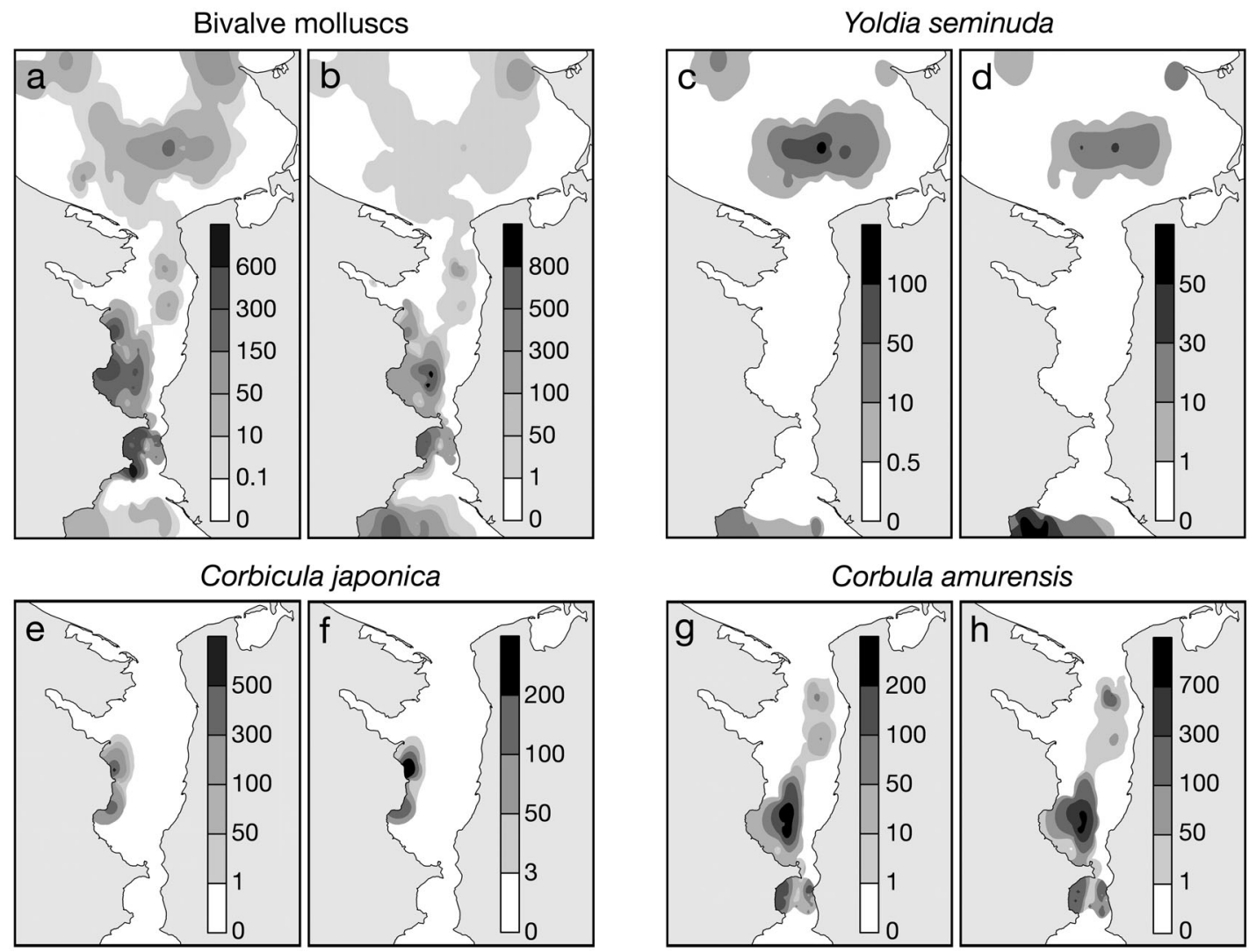

Mytilus trossulus

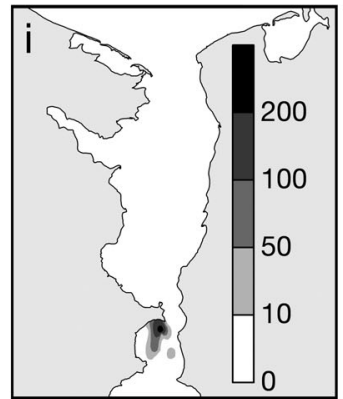

Biomass ( $\mathrm{g}$ wet wt $\mathrm{m}^{-2}$ )

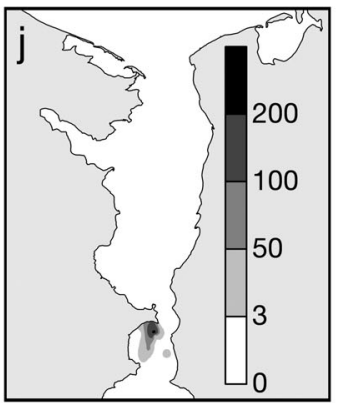

Density (ind. $\mathrm{m}^{-2}$ )

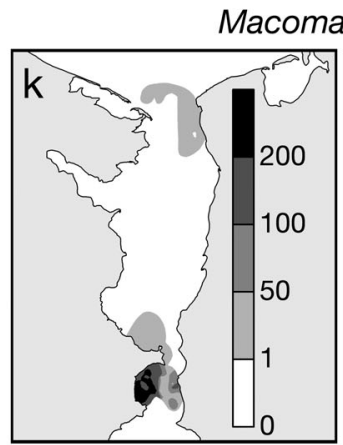

Biomass (g wet wt $\mathrm{m}^{-2}$ )

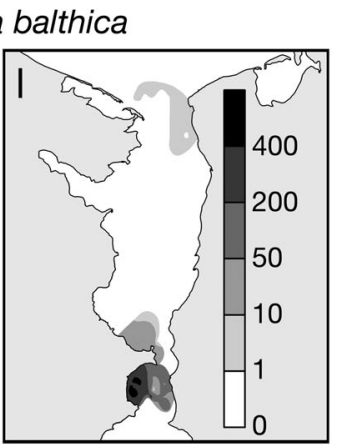

Density (ind. $\mathrm{m}^{-2}$ )

Fig. 2. Biomass and density of $(\mathrm{a}, \mathrm{b})$ all bivalve molluscs and the dominant bivalve species: (c,d) Yoldia seminuda, (e,f) Corbicula japonica, $(\mathrm{g}, \mathrm{h})$ Corbula amurensis, $(\mathrm{i}, \mathrm{j})$ Mytilus trossulus, and $(\mathrm{k}, \mathrm{l})$ Macoma balthica, in the Amur River estuary. Data were averaged among samples at each station

$0.4 \mathrm{psu}$ ) (Table S2) soft sediments were dominated by widely distributed North Pacific species: Yoldia seminuda (frequency index 42.1\%), Ennucula tenuis $(47.4 \%)$ and Siliqua alta $(36.8 \%)$. These species were the most responsible for the withingroup similarity of stations in the area $\mathrm{T}$ (Table 2). Warm-water species Callithaca adamsi, Venerupis phillippinarum and Raeta pulchella were recorded at low abundance in a small number of samples. On gravel substrate at Cape Nevelskoy, the dominant species was warm-water Crassostrea gigas (biomass up to $1174 \mathrm{~g}$ wet wt $\mathrm{m}^{-2}$, density 27 ind $\mathrm{m}^{-2}$ ). Warm-water species, i.e. C. gigas and Raeta pulchella along with $Y$. seminuda, E. tenuis and $S$. alta, were the most responsible for discriminating area $\mathrm{T}$ from the others in the Amur estuary (Table 3). In the area of transition to the central estuary (area ET) with a lower salinity and higher water temperature compared to area T (Table S2), we found only Macoma balthica, Corbula amurensis and Mytilus trossulus. Macoma balthica and C. amurensis dominated on silty sands and silts 

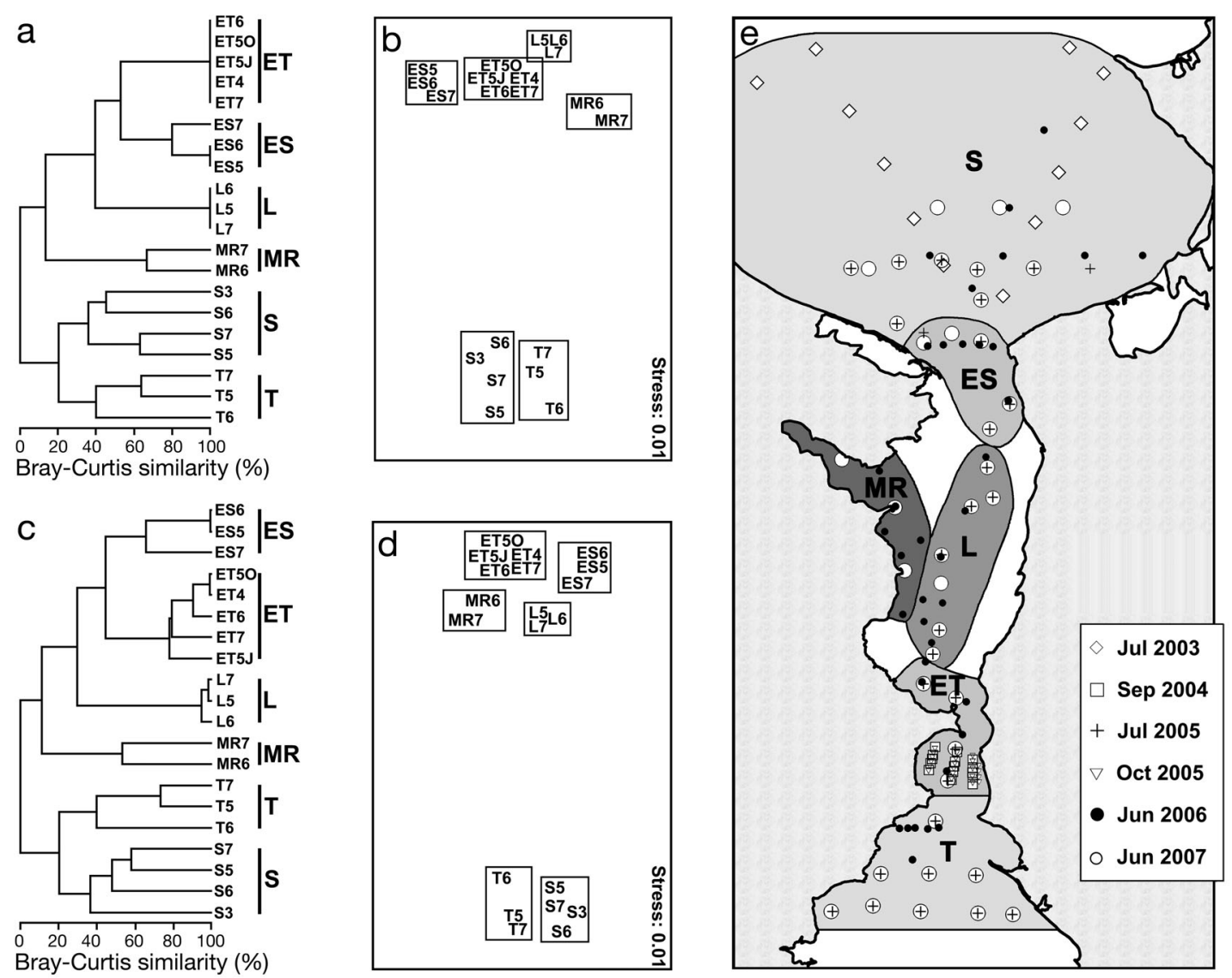

Fig. 3. (a,b) Cluster and multidimensional scaling (MDS) analyses based on qualitative (presence/absence of species) and (c,d) quantitative (fourth-root transformed biomass) similarities (Bray-Curtis measure) amongst the bivalve molluscan assemblages found for all years of study in (e) the different areas of the Amur River estuary. The boxes in MDS plots represent the 6 main station groups in dendrograms. Abbreviations are a combination of station groups and sampling date: T, Tatar Strait; ET, exit to Tatar Strait; L, Amurskiy Liman; MR, mouth of river; ES, exit to Sakhalin Gulf; S, Sakhalin Gulf; 3, July 2003; 4, September $2004 ;$, July 2005; 5O, October 2005; 6, June 2006; 7, June 2007

(Fig. 2, Table 2). Mytilus trossulus was only observed to the south of Cape Lazarev on gravel (Fig. 2).

The central estuary (area L) is characterized a low average salinity (mean \pm SE: $18.2 \pm 2.1 \mathrm{psu}$ ), a relatively high water temperature $\left(11.8 \pm 0.6^{\circ} \mathrm{C}\right)$, and great variability of these parameters among the sampling stations in the different parts of this area (Table S2). Only one warm-water species, Corbula amurensis, was found at high abundance in this area (Fig. 2). Its lowest abundance was observed only in ship channels. The area adjacent to the Amur River mouth (area MR) with the highest temperature of near-bottom water $\left(15.8 \pm 0.6^{\circ} \mathrm{C}\right)$ and the lowest salinity (2.4 $\pm 1.5 \mathrm{psu})$ (Table S2) was dominated by another warm-water species, Corbicula japonica (Fig. 2). In the MR area, C. amurensis was only found co-occurring with $C$. japonica in the southernmost part at the Chastye Islands in the transition zone between the areas $\mathrm{L}$ and MR. At the exit from Amurskiy Liman to Sakhalin Gulf (area ES) with relatively high salinity $(20.6 \pm 3.2 \mathrm{psu})$ and moderate temperature $\left(8.5 \pm 2.1^{\circ} \mathrm{C}\right.$ ) (Table S2), only Macoma balthica and $C$. amurensis form assemblages with low abundance (Fig. 2). The dominant species was M. balthica, which occurred at most stations (87.5\%). The warm-water species $C$. amurensis was found cooccurring with $M$. balthica in the southern part of the ES area in the transition zone to area L.

The northern estuary, including almost the entire Sakhalin Gulf (area S), is characterized by very low water temperature near the bottom (mean \pm SE: -0.9 $\left.\pm 0.2^{\circ} \mathrm{C}\right)$ and high salinity $(32.9 \pm 0.1 \mathrm{psu})$ (Table S2). The highest species richness and abundance of bivalves were observed in the central and northeastern Sakhalin Gulf on silty sands and silts (Fig. 2). In the southern gulf, at the entrance to Amurskiy Liman, bivalve biomass did not exceed $1 \mathrm{~g}$ wet 

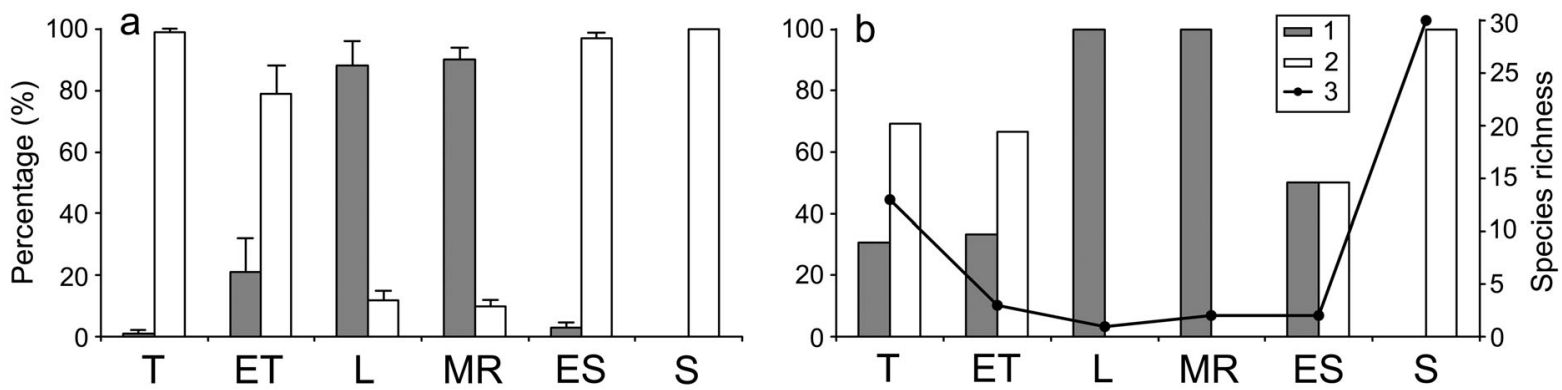

Fig. 4. (a) The proportion (\%) of warm-water species of bivalves in total macrobenthos biomass per station (mean + SE) and (b) in species richness of brackish-water and marine bivalves in the different areas of the Amur River estuary (based on the pooling of multi-year sampling data). 1, warm-water species of bivalves; 2, widely-distributed species; 3, species richness; $T$, Tatar Strait; ET, exit to Tatar Strait; L, Amurskiy Liman; MR, mouth of river; ES, exit to Sakhalin Gulf; S, Sakhalin Gulf

wt $\mathrm{m}^{-2}$. The dominant and most widely distributed species in Sakhalin Gulf were common North Pacific species: Yoldia seminuda (frequency index $38.2 \%$ ), Yoldia myalis $(26.5 \%)$, Serripes groenlandicus $(32.4 \%)$, Tellina lutea (17.6\%) and Macoma calcarea $(26.5 \%)$. They were the most responsible for the within-group similarity of stations in the area $\mathrm{S}$ (Table 2) and made the main contribution to the difference of this area from the other investigated areas in the Amur estuary (Table 3).

Table 2. Results from SIMPER analysis of bivalve molluscs data (fourth-root transformed biomass), listing the main characterizing species within each different area of the Amur River estuary (to a total of $90 \%$ contributions). S, Sakhalin Gulf; ES, exit to Sakhalin Gulf; L, Amurskiy Liman; MR, mouth of river; ET, exit to Tatar Strait; T, Tatar Strait

\begin{tabular}{|c|c|c|c|c|}
\hline $\begin{array}{l}\text { Area } \\
\text { of } \\
\text { estuary }\end{array}$ & Species & $\begin{array}{c}\text { Average } \\
\text { biomass } \\
\left(\mathrm{g} \text { wet wt } \mathrm{m}^{-2} \text { ) }\right.\end{array}$ & $\begin{array}{c}\text { Average } \\
\text { similarity } \\
(\%)\end{array}$ & $\begin{array}{c}\text { Contribution } \\
(\%)\end{array}$ \\
\hline $\begin{array}{l}\mathrm{T} \\
\text { Average }\end{array}$ & $\begin{array}{l}\text { Siliqua alta } \\
\text { Ennucula tenuis } \\
\text { Yoldia seminuda } \\
\text { similarity } 24.0 \%\end{array}$ & $\begin{array}{l}4.9 \\
1.7 \\
5.1\end{array}$ & $\begin{array}{r}10.0 \\
7.0 \\
5.4\end{array}$ & $\begin{array}{l}41.8 \\
29.1 \\
22.6\end{array}$ \\
\hline Average & $\begin{array}{l}\text { Yoldia seminuda } \\
\text { Serripes groenlandicus } \\
\text { Yoldia myalis } \\
\text { Macoma calcarea } \\
\text { Tellina lutea } \\
\text { similarity } 24.1 \%\end{array}$ & $\begin{array}{r}14.9 \\
5.5 \\
2.2 \\
0.5 \\
3.2\end{array}$ & $\begin{array}{l}5.5 \\
3.6 \\
1.3 \\
1.1 \\
1.1\end{array}$ & $\begin{array}{r}39.3 \\
25.5 \\
9.1 \\
8.0 \\
8.0\end{array}$ \\
\hline $\begin{array}{l}\text { ES } \\
\text { Average }\end{array}$ & $\begin{array}{l}\text { Macoma balthica } \\
\text { similarity } 68.7 \%\end{array}$ & 6.3 & 66.3 & 96.6 \\
\hline $\begin{array}{l}\mathrm{L} \\
\text { Average }\end{array}$ & $\begin{array}{l}\text { Corbula amurensis } \\
\text { similarity } 74.2 \%\end{array}$ & 133.3 & 74.2 & 100.0 \\
\hline $\begin{array}{l}\text { ET } \\
\text { Average }\end{array}$ & $\begin{array}{l}\text { Macoma balthica } \\
\text { Corbula amurensis } \\
\text { similarity } 72.0 \%\end{array}$ & $\begin{array}{l}95.9 \\
54.2\end{array}$ & $\begin{array}{l}46.6 \\
23.2\end{array}$ & $\begin{array}{l}64.7 \\
32.3\end{array}$ \\
\hline $\begin{array}{l}\text { MR } \\
\text { Average }\end{array}$ & $\begin{array}{l}\text { Corbicula japonica } \\
\text { similarity } 79.3 \%\end{array}$ & 148.6 & 77.9 & 98.2 \\
\hline
\end{tabular}

\section{Linking bivalve distribution and environmental factors}

BIOENV analyses of abundance data showed that a large amount of the biological variation (correlation coefficient, range 0.495 to 0.582 ) can be explained by 4 environmental variables; additional variables add little to the correlation. These relationships are statistically significant: the 5 models displayed in Table 4 each gave $\mathrm{p}<0.001$ using RELATE procedure. Therefore, the best combination of environmental variables explaining the variability of the biotic parameters is depth, temperature, salinity, and clay content. Nutrient and oxygen concentrations in water near the bottom did not influence the bivalve distribution.

The biomass of brackish-water Corbula amurensis, Corbicula japonica and Macoma balthica, which dominated in areas with reduced salinity (ES, ET, L, MR), was negatively related to the salinity of the nearbottom water layer (Table 4). The biomass of warm-water species C. amurensis and $C$. japonica was positively correlated with the temperature of the water near the bottom. Moreover, the distribution of $C$. amurensis and $M$. balthica was positively related to the clay content of sediment. Substrate availability was largely responsible for the distribution of Mytilus trossulus in the estuary. There was a relatively high correlation $(\rho=0.46)$ between its biomass distribution and gravel content of sediment. The dis- 


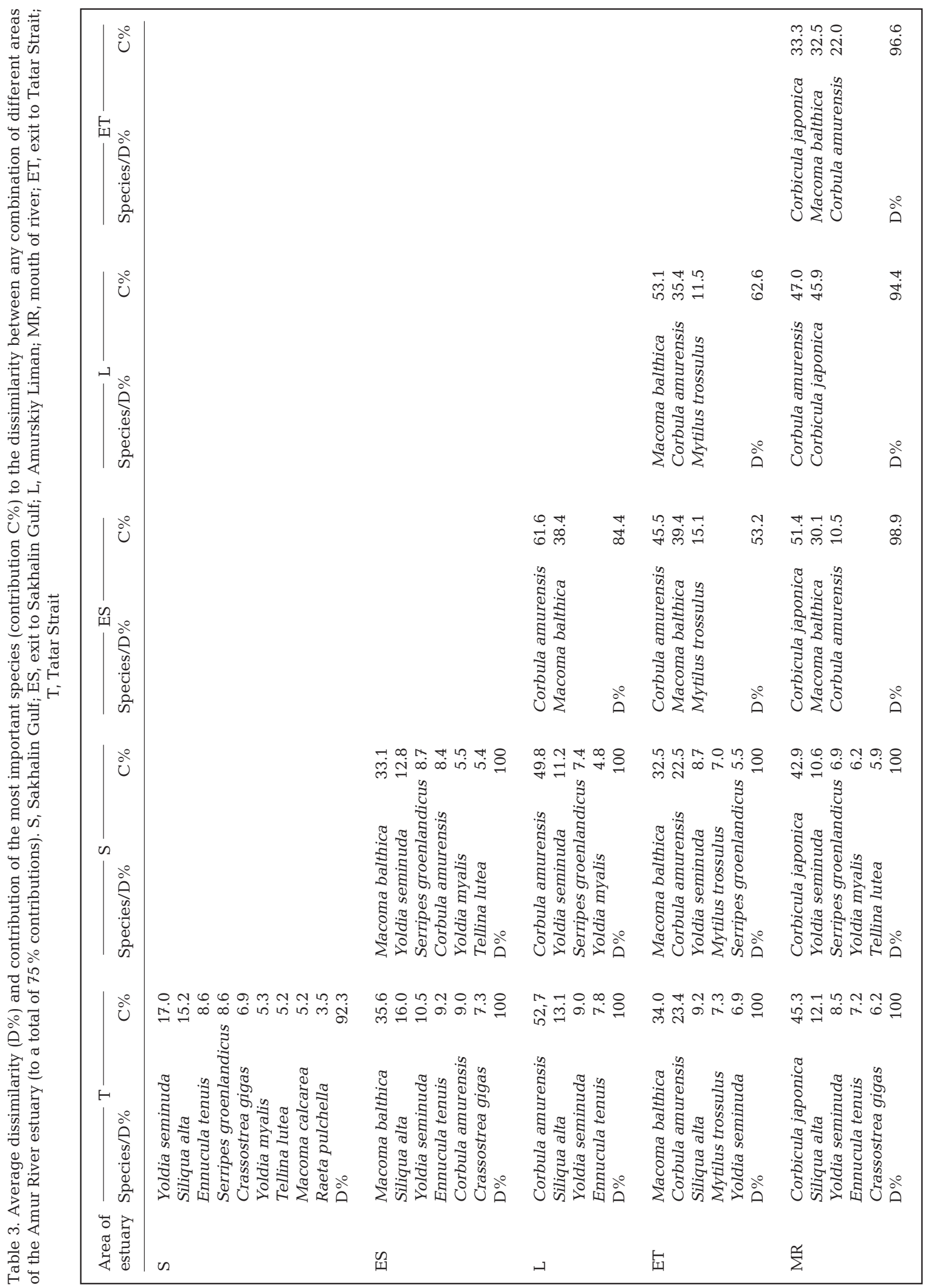


tribution of typical marine surface deposit feeders Yoldia seminuda, Yoldia myalis, Ennucula tenuis and Macoma calcarea, which dominated in Sakhalin Gulf and the Tatar Strait, was positively related to water salinity and clay content of sediment but (except the distribution of E. tenuis) was negatively related to water temperature. Another dominant species, Serripes groenlandicus, occurred in marine areas on various substrates, while Siliqua alta was mainly found on sands $(\rho=0.45)$ with a low content of silt and clay. Depth also influences the distribution of most dominant species. Increase in depth occurs in the seaward parts of the estuary (areas S and T) where temperature and salinity change markedly (Table S2). Therefore, the change in depth primarily reflects the change in temperature and salinity of the near-bottom water layer, which largely affect the distribution of species in the estuary.

\section{DISCUSSION}

Our study shows that the composition and distribution of the bivalve assemblages in the Amur estuary primarily reflect the specific hydrochemical characteristics of water in the estuary, which have not changed over the last $70 \mathrm{yr}$. The 6 areas of the Amur estuary distinguished herein based on the similarity of bivalve species composition correspond to the areas singled out by Ushakov $(1940,1948)$ in his analysis of macrobenthic species composition. We believe that water temperature is one of the major determinants of bivalve composition and distribution in the Amur estuary. Despite its location in the northern latitudes, surrounded by the cold-water Sea of Okhotsk and northern Sea of Japan, the Amur estuary is inhabited by warm-water marine (Venerupis philippinarum, Crassostrea gigas, Raeta pulchella, Callithaca adamsi) and brackishwater (Corbicula japonica and Corbula amurensis) species of bivalves (Table S1). Besides, one more warm-water bivalve Protothaca euglypta was indicated for the fauna of the Nevelskoy Strait (Labay 2004). All warm-water marine species were found only in the relatively warm southern part of the estuary (area T), which is the northern distribution limit of these species along the Asiatic continent. In the
Amur estuary, these marine species form isolated populations with low abundance and were previously known only in more southerly areas of the Sea of Japan (Scarlato 1981, Okutani 2000, Kantor \& Sysoev 2005). In the greater part of the cold-water northern Sea of Japan they are only encountered in shallow well-warmed areas of fairly closed bays. All these euryhaline marine species are able to endure slight freshening and can inhabit reduced-salinity waters (Scarlato 1981, Komendantov \& Orlova 2003). To date, $C$. gigas and $V$. philippinarum are widely distributed in the Northern Hemisphere and are of major importance to both the wild fishery and aquaculture industry worldwide (Coan et al. 2000, Robinson et al. 2005). However, southern Amurskiy Liman is the northern distribution limit of their natural populations. In contrast to marine warm-water species, warm-water brackish C. japonica and C. amurensis dominate the macrobenthos in the warm oligohaline and mesohaline zones of the central estuary (Fig. 2, Table S1). They are widely distributed in estuaries, lagoons and salt lakes of southeast Asia (up to $45^{\circ} \mathrm{N}$ ), southern Sakhalin Island, and in Japan, where they 
dominate the benthic communities (Scarlato 1981, Okutani 2000, Yavnov \& Rakov 2002, Komendantov \& Orlova 2003). These species are also found in Piltun Bay on the northeastern coast of Sakhalin (Kafanov et al. 2003). Local populations of C. japonica near the Amur River mouth have long been known (Ushakov 1940, 1948, Yavnov \& Rakov 2002, Dulenina 2003). In addition, within Amurskiy Liman C. japonica was found at Cape Khalezov and from Cape Puir to Cape Menshikov, as well as outside Amurskiy Liman, at its northern border, in Schastye Bay (Yavnov \& Rakov 2002, Dulenina 2003, Dulenina \& Dulenin 2009) (Fig. 1a). Corbula amurensis was relatively recently (1986 to 1987) introduced into San Francisco Bay (California, USA), where at some localities it dominates the macrobenthos (Carlton et al. 1990, Nichols et al. 1990, Greene et al. 2011). Scarlato (1981) notes that $C$. amurensis was also recorded in Tugur Bay (Sea of Okhotsk) situated to the north of the Amur estuary. However, these data need to be verified because material of this species from Tugur Bay was lacking from the Zoological Institute collection (Saint Petersburg) examined by Scarlato (1981). Thus, the Amur estuary, which is situated more than $700 \mathrm{~km}$ away from the main ranges of $C$. japonica and $C$. amurensis, is also the northern distribution limit of these brackish-water species along the Asiatic continent. In the Amur estuary, these species have formed populations that are isolated from their main ranges. All warm-water species found in the estuary are highly eurythermal species with temperature tolerances ranging from from -1.5 to $30^{\circ} \mathrm{C}$ (Carlton et al. 1990, Coan et al. 2000, Yavnov \& Rakov 2002). However, temperature influences the spawning and larval growth of these species to a greater extent (Baba et al. 1999, Kimura et al. 2004); they only spawn at a temperature greater than $15^{\circ} \mathrm{C}$ (Kasyanov et al. 1998, Nicolini \& Penry 2000, Kimura et al. 2004). Thus, the high water temperature in the southern and central estuary during the summer, which is anomalous for these latitudes, is favourable for the reproduction and juvenile survival of warmwater species in this region.

In the temperate latitudes of the northwestern Pacific, the fauna in sheltered well-warmed bays and lagoons contains more warm-water species than on the open coasts (Scarlato 1981, Kafanov et al. 2003). Some warm-water species of macrobenthos inhabit such far northern embayments warmed-up during the summer in relatively cold-water regions of the Seas of Japan and Okhotsk, because high summer temperature allows them to complete the reproductive cycle. They form populations isolated from their main ranges that have been preserved since the Late Holocene cooling (Lutaenko 1991). The penetration of warm-water organisms from one well-warmed area to another may have occurred in periods of climate warming and heating of surface water in intermediate, cold regions of the sea (Scarlato 1981, Lutaenko 1993, 1999). Thus, the Amur estuary is the northernmost region of the northwestern Pacific where, due the intensive warming-up of shallowwater in summer and the input of warm Amur River water from the south of the continent, there are favourable conditions for the existence of warmwater marine and brackish-water species. As is the case for southern warm-water estuaries, the macrobenthos of the central Amur estuary is dominated by warm-water species, which determine the bottom community abundance and structure. This confirms our hypothesis that the Amur estuary promotes the farther north distribution of warm-water species, greatly influencing the species diversity of the coldwater northwestern Pacific region.

Undoubtedly, the composition and distribution of bivalves in the Amur estuary are also greatly affected by many other environmental factors, among them salinity, bottom current velocity, sediment stability, sedimentation processes. The densest populations of bivalves in Amurskiy Liman were confined to shallow-water areas with decreased dynamics of water and high sediment clay content (Figs. 1d \& 2), whereas the lowest bivalves abundance was recorded on the bottom of ship channels with more active hydrodynamics of near-bottom water and low sediment clay content. In the greatly freshened central part of the estuary (western MR [except the Amur River mouth], L, ES, northern ET areas), we found only brackish-water Corbicula japonica, Corbula amurensis and Macoma balthica (Table S1). Each of the species dominates a specific, fairly well-defined zone of the estuary, which differs mainly in the values and variability of salinity (Fig. 2, Table S2). Strictly marine and marine eurytopic species were found in the deep-water northern and southern parts of the estuary only (i.e. Sakhalin Gulf and the northern Tatar Strait) (Table S1), where riverine water has a marked effect on superficial water (Zhabin et al. 2007 , 2009). Low salinity is the main limiting factor that hampers the spread of marine species from the Seas of Okhotsk and Japan into central Amurskiy Liman. Josefson \& Hansen (2004) have showed that the species richness of estuaries is greatly affected by the degree of penetration of marine waters into estuaries, which carry planktonic larvae of various marine animals. On the other hand, estuaries of the 
great Siberian rivers with relatively warmer waters allow relic estuarine and boreal marine faunas the opportunity to survive in Arctic seas (Golikov et al. 1994, Deubel et al. 2003, Denisenko et al. 2007, Denisenko 2010). Ushakov $(1948,1953)$ emphasized the particular role of the longitudinally extended and greatly freshened Amurskiy Liman, where sharp fluctuations of various environmental factors exist and provide a barrier to strictly marine animals by preventing an active exchange of faunas across the Seas of Japan and Okhotsk. However, considering the current system of the estuary in summer, it is quite probable that brackish-water and eurytopic marine species of bottom animals, whose larvae are most tolerant to adverse environmental conditions, could be transported from the southern and central parts of Amur estuary to other regions of the northwestern Pacific. The plume of warm and freshened water from Amurskiy Liman extends for $200 \mathrm{~km}$ northwards into the Sea of Okhotsk, along northeastern Sakhalin inclusive (Dudarev et al. 2000). Kafanov et al. (2003) deem that many warm-water species, among them the brackish-water bivalves $C$. japonica and $C$. amurensis, must have spread via these waters to well-heated lagoons of northeastern Sakhalin Island (Fig. 1a,c). The warm-water lagoons of northeastern Sakhalin surrounded by cold waters of the Sea of Okhotsk might have also been a refugium for the pre-Pleistocene warm-water biota of the Sea of Okhotsk that disappeared after the Neogene cooling (Kafanov et al. 2003). It is not excluded that one of the places of warm-water fauna preservation might have been the warm-water Amur estuary, from which warm-water species could have spread to the lagoons of northeastern Sakhalin.

Labay (2004) considers only southern Amurskiy Liman (Nevelskoy Strait) (Fig. 1a) as a refugium for a number of macrobenthic species of the subtropical and tropical origin. Our study suggests that not only the Nevelskoy Strait but the entire Amurskiy Liman serves the role of a refugium for many warm-water species of bottom animals of the northwestern Pacific. As is the case with a number of bivalves, Amurskiy Liman is the northern distribution limit and frequently an isolated part of the species' ranges of warm-water species, such as the isopod Ichthyoxenus amurensis, the polychaetes Travisia japonica, Pectinaria dima, mud shrimp Upogebia major, and the crabs Paracleistostoma cristatum, Hemigrapsus penicillatus and Eriocheir japonicus (Ushakov 1940, 1948, Labay 2004, I. Alalykina pers. comm.). The warm-water anomaly in Amurskiy Liman is probably conducive to the conservation of remnants of the warm-water fauna that had existed in the northwestern Pacific during the Paleogene-Early Neogene (Kafanov et al. 2003).

Many investigators consider Amurskiy Liman as a well-defined biogeographic boundary on the Asiatic continent separating the North Pacific biogeographic region into the Japanese-Manchurian low-boreal subregion with relatively warm-water marine fauna and the Beringian high-boreal subregion with coldwater fauna (reviews Kussakin 1979, Scarlato 1981, Kafanov 1991). The provincial boundaries usually occur along the coast in places where many species reach their range limits (Kafanov 1991, Mironov 2004). The main criterion for the demarcation between the 2 North Pacific subregions is primarily the northern distribution limits of warm-water families of marine organisms. Thus, the northern boundary of the warm-water Japanese-Manchurian subregion on the Asian continent was assumed to lie at the latitude of Chikhachev Bay (Fig. 1a). This bay was the northern distribution boundary of Crassostrea gigas - the only representative of the warm-water family Ostreidae (Kafanov 1991). In reality, this euryhaline marine species occurs much farther north, in the southern part of the Amur estuary (Cape Nevelskoy) (Fig. 1a). We, therefore, suggest that the northern boundary of the marine Japanese-Manchurian biogeographic subregion is the southern part of the Amur estuary (at the latitude of Cape Nevelskoy), where C. gigas occurs along with some other warm-water euryhaline marine species. Undoubtedly, the oblong Amur River estuary (300 km longitudinally) is the place of contact of warm- and cold-water marine and brackish-water bivalve faunas of the northwestern Pacific. The northern Tatar Strait and Amurskiy Liman is the northern limit of distribution along the Asiatic coast of 7 warm-water marine and brackish-water species, which comprise 35 to $67 \%$ of the bivalve fauna of these areas, respectively (Table S1). On the other hand, the bivalve fauna of Sakhalin Gulf and coastal waters of northeastern Sakhalin includes not only widely distributed boreal-arctic species but also rare species for the northern Pacific and species largely characteristic only of the Arctic Ocean fauna (Lampeia adamsi, Montacuta spitzbergensis and Cyrtodaria curiana) (Kamenev \& Nadtochy 1998, Kamenev 2008, G. Kamenev unpubl. results). Moreover, the Amur estuary is the southern limit of the ranges of some other species of macrobenthic invertebrates (for example, the brackish-water isopod Saduria entomon, common in arctic estuaries) (Khlebovich 1986, Labay 2004). Temperature and global climate change have been cited as the most important factors 
governing marine biogeographical provinces (Kafanov 1991, Engle \& Summers 1999). However, species may also be confined to biogeographical regions by barriers that are physical, geomorphological, chemical, or spatial (Golikov et al. 1990, Mironov 2004). Thus, the Amur estuary with its sharp gradient of water temperature from the southern to the northern parts, as well as a greatly freshened central part, provides both a temperature and physical barrier separating the warm- and cold-water marine faunas of the northwestern Pacific.

In conclusion, the Amur estuary, which hosts many marginal, often isolated populations of both warmand cold-water marine and brackish-water species, is a unique ecosystem, which greatly influences the species diversity of macrobenthos in the northwestern Pacific. However, the composition and structure of bottom communities determined in most of the estuary by warm-water species are very vulnerable. Marginal populations of these species often occur in small sizes which, combined with the harshness of local conditions, may reduce their resistance and resilience to further natural or anthropogenic disturbances. Under such circumstances, further reduced and isolated populations might not be able to respond efficiently to more extreme environmental conditions, such as those predicted with climate change (Engle \& Summers 1999, Lutaenko 1999). This highlights the need for management and protection measures that would allow the conservation of the distinctive traits of the Amur estuary and the preservation of this unique northern Pacific ecosystem.

Acknowledgements. We are very grateful to Dr. V. Ivin (A. V. Zhirmunsky Institute of Marine Biology, IMB, Vladivostok) for assistance in the data analysis and much help during this work; to Drs. O. Dudarev, A. Botsul, and I. Zhabin (V. I. Il'ichev Pacific Oceanological Institute, POI, Vladivostok) for providing the hydrochemical characteristics of the water column and the sediment grain size data; to Drs. E. Sayenko and L. Prozorova (Institute of Biology and Soil Science, Vladivostok) for identification of fresh-water species of bivalves; to Drs. V. Labay (Sakhalin Research Institute of Fishery and Oceanography, Yuzhno-Sakhalinsk), I. Alalykina and O. Golovan (IMB) for information about the distribution of some macrobenthic species in the Amur estuary; to Dr. A. Mironov (Institute of Oceanology, Moscow) and Ms. N. Khodorenko (POI) for sending copies of scientific papers necessary for this work; to Dr. I. Yakovleva for consultation and discussion of some issues; to Dr. P. Kijashko (Zoological Institute, Saint Petersburg) for informing about materials of some bivalve species from the Amur estuary deposited in the Zoological Institute collection; to Ms. T. Koznova (IMB) for help with translating the manuscript into English. Thanks are also due to the editor responsible, Dr. R. Osman, and anonymous reviewers for valuable comments, suggestions, and constructive criticism.
This research was partly supported by the Far Eastern Branch of the Russian Academy of Sciences (grant no. 09-IIIA-06-203) and the Russian Foundation for Basic Research (grants nos. 09-05-00868-a and 11-04-00328-a).

\section{LITERATURE CITED}

Anderson MJ, Diebel CE, Bloom WM, Landers TJ (2005) Consistency and variation in kelp holdfast assemblages: spatial patterns of biodiversity for the major phyla at different taxonomic resolutions. J Exp Mar Biol Ecol 320: $35-56$

> Baba K, Tada M, Kawajiri T, Kuwahara Y (1999) Effects of temperature and salinity on spawning of the brackish water bivalve Corbicula japonica in Lake Abashiri, Hokkaido, Japan. Mar Ecol Prog Ser 180:213-221

Beseres Pollack JB, Palmer TA, Montagna PA (2011) Longterm trends in the response of benthic macrofauna to climate variability in the Larvaca-Colorado Estuary, Texas. Mar Ecol Prog Ser 436:67-80

Bray JR, Curtis JT (1957) An ordination of the upland forest communities of Southern Wisconsin. Ecol Monogr 27: 325-349

Carlton JT, Thompson JK, Schemel LE, Nichols FH (1990) Remarkable invasion of San Francisco Bay (California, USA) by the Asian clam Potamocorbula amurensis. I. Introduction and dispersal. Mar Ecol Prog Ser 66:81-94

Clarke KR (1993) Non-parametric multivariate analyses of changes in community structure. Aust J Ecol 18:117-143

Clarke KR, Ainsworth M (1993) A method of linking multivariate community structure to environmental variables. Mar Ecol Prog Ser 92:205-219

Clarke KR, Gorley RN (2001) PRIMER (Plymouth Routines In Multivariate Ecological Research) v5: User Manual/Tutorial. PRIMER-E, Plymouth

Clarke KR, Warwick RW (2001) Change in marine communities: an approach to statistical analysis and interpretation, 2nd edn. PRIMER-E, Plymouth

Coan EV (2002) The eastern Pacific recent species of the Corbulidae (Bivalvia). Malacologia 44:47-105

Coan EV, Scott PV, Bernard FR (2000) Bivalve seashells of western North America. Marine bivalve mollusks from Arctic Alaska to Baja California. Santa Barbara Museum of Natural History, Santa Barbara, CA

Day JW, Hall CAS, Kemp WM, Yáñez-Arancibia A (1989) Estuarine ecology. Wiley-Interscience, New York, NY

> Denisenko NV (2010) The description and prediction of benthic biodiversity in high arctic and freshwater-dominated marine areas: the southern Onega Bay (the White Sea). Mar Pollut Bull 61:224-233

- Denisenko NV, Denisenko SG, Lehtonen KK, Andersin AB, Sandlier HR (2007) Zoobenthos of the Cheshkaya Bay (southern Barents Sea): spatial distribution and community structure in relation to environmental factors. Polar Biol 30:735-746

Deubel H, Engel M, Fetzer I, Gagaev S and others (2003) The southern Kara Sea ecosystem: phytoplankton, zooplankton and benthos communities influenced by river run-off. In: Stein R, Fahl K, Fütterer DK, Galimov EM, Stepanets OV (eds) Siberian river run-off in the Kara Sea: characterisation, quantification, variability and environmental significance. Proceedings in Marine Science, Vol 6. Elsevier, Amsterdam, p 237-265

Dudarev OV, Botsul AI, Anikeev VV, Yakunin LP, Koselov 
GM (2000) Modern sedimentation in the estuary of the Amur River. Tikhookeanskaya Geologiya 19:30-43 (in Russian with English Abstract)

Dulenina PA (2003) Brackish-water clam (Corbicula japonica) of internal aquatories and river estuaries of Khabarovsk region: an information review. Vladimir Ya. Levanidov's Biennial Memorial Meetings 2:153-159 (in Russian with English Abstract)

Dulenina PA, Dulenin AA (2009) The distribution and biological parameters of Asiatic clam Corbicula japonica in the Amur River estuary. In: Chelomin VP (ed) Condition of marine ecosystems influenced by the Amur River flow. Dalnauka, Vladivostok, p 193-201 (in Russian with English Abstract)

Engle VD, Summers JK (1999) Latitudinal gradients in benthic community composition in Western Atlantic estuaries. J Biogeogr 26:1007-1023

Golden Software (2002) SURFER for Windows, Version 8 User's Guide. Golden Software, Golden, CO

Golikov AN, Dolgolenko MA, Maximovich NV, Scarlato OA (1990) Theoretical approaches to marine biogeography. Mar Ecol Prog Ser 63:289-301

Golikov AN, Gagaev SY, Galtzova VV, Golikov AA and others (1994) Ecosystems and the flora and fauna of the Chaun Bay of the East-Siberian Sea. In: Scarlato OA (ed) Ecosystems and the flora and fauna of the Chaun Bay of the East-Siberian Sea, Part 1. Zoological Institute, Saint Petersburg, p 4-111 (in Russian with English Abstract)

Gray JS (2002) Species richness of marine soft sediments. Mar Ecol Prog Ser 244:285-297

Gray JS, Bjørgesæter A, Ugland KI (2005) The impact of rare species on natural assemblages. J Anim Ecol 74: 1131-1139

Greene VE, Sullivan LJ, Thompson JK, Kimmerer WJ (2011) Grazing impact of the invasive clam Corbula amurensis on the microplankton assemblage of the northern San Francisco Estuary. Mar Ecol Prog Ser 431:183-193

> Herman PMJ, Middelburg JJ, Van De Koppell J, Heip CHR (1999) Ecology of estuarine macrobenthos. Adv Ecol Res 29:195-240

Hill T, Lewicki P (2006) Statistics: method and applications. Statsoft, Tulsa, OK

Josefson AB, Hansen JLS (2004) Species richness of benthic macrofauna in Danish estuaries and coastal areas. Glob Ecol Biogeogr 13:273-288

Kafanov AI (1991) Bivalve molluscs and faunistic biogeography of the northern Pacific. Far East Branch of Academy of Sciences of the USSR, Vladivostok

Kafanov AI, Labay VS, Pecheneva NV (2003) Biota and macrobenthic communities of the northeast Sakhalin lagoons. Sakhalin Research Institute of Fisheries \& Oceanography, Yuzhno-Sakhalinsk (in Russian with English Abstract)

Kamenev GM (2008) Little-known arctic species Montacuta spitzbergensis (Bivalvia: Montacutidae) from the northwestern Pacific with notes on Montacuta substriata and Tellimya ferruginosa. J Mar Biol Assoc UK 88:347-356

Kamenev GM, Nadtochy VA (1998) Two new species of Lampeia (Bivalvia: Thraciidae) from the Northwestern Pacific, with notes on Lampeia adamsi (MacGinitie, 1959). Veliger 41:259-273

Kantor YuA, Sysoev AV (2005) Catalogue of molluscs of Russia and adjacent countries. KMK Scientific Press, Moscow

Kasyanov VL, Kryuchkova GA, Kulikova VA, Medvedeva
LA (1998) Larvae of marine bivalves and echinoderms. Amerind Publishing, New Delhi

Khlebovich VV (1986) On biological typology of estuaries of the USSR. In: Khlebovich VV (ed) Hydrobiological investigations of estuaries. Zoological Institute, Leningrad, p 5-16 (in Russian with English Abstract)

Kimura T, Soutome Y, Sekiguchi H (2004) Larval development of the brackish water clam Corbicula japonica (Bivalvia: Corbiculidae), with special reference to morphological comparison with concurrent tidal flat bivalves. Venus 63:33-48

Komendantov AY, Orlova MI (2003) Ecology of estuarine bivalve mollusks and polychaetes of south Primorye. Zoological Institute, Saint Petersburg (in Russian with English Abstract)

Kraufvelin P, Perus J, Bonsdorff E (2011) Scale-dependent distribution of soft-bottom infauna and possible structuring forces in low diversity systems. Mar Ecol Prog Ser 426:13-18

Kussakin OG (1979) Marine and brackish-water isopod crustaceans (Isopoda) of cold and temperate waters of the Northern Hemisphere. Suborder Flabellifera. Nauka, Leningrad

Labay VS (2004) Macrobenthos of Nevelskoy Strait. Trans Sakhalin Res Inst Fish Oceanogr 6:305-330 (in Russian with English Abstract)

Lizova AV (2007) On the problem of the Amur River transboundary pollution influence on water biological resources and their environment. Izv TINRO 148:262-274

Luchin VA (2007) Seasonal variability of water temperature in the active layer of the Far Eastern seas. In: Akulichev VA (ed) Far Eastern Seas of Russia (in 4 books). Book 1. Oceanological studies. Nauka, Moscow, p 232-252 (in Russian)

Lutaenko KA (1991) On origin of warm-water elements of malacofauna of Peter the Great Bay, Sea of Japan. Biol Morya 1:12-20 (in Russian with English Abstract)

Lutaenko KA (1993) Climatic optimum during the Holocene and the distribution of warm-water mollusks in the Sea of Japan. Palaeogeogr Palaeoclimatol Palaeoecol 102: 273-281

Lutaenko KA (1999) Expected faunal changes in the Sea of Japan: influence of climate and sea level on the distribution of bivalve mollusks. Bull Russian Far East Malacol Soc 3:38-64 (in Russian with English Abstract)

McLusky DS, Elliott M (2004) The estuarine ecosystem: ecology, threats and management, 3rd edn. Oxford University Press, Oxford

Mironov AN (2004) Nature of the biotic boundaries. In: Kafanov AI (ed) Main problems in marine biogeography: in memory of the academician O.G. Kussakin. Dalnauka, Vladivostok, p 67-97 (in Russian with English Abstract)

> Nichols FH, Thompson JK, Schemel LE (1990) Remarkable invasion of San Francisco Bay (California, USA) by the Asian clam Potamocorbula amurensis. II. Displacement of a former community. Mar Ecol Prog Ser 66:95-101

Nicolini MH, Penry DL (2000) Spawning, fertilization, and larval development of Potamocorbula amurensis (Mollusca: Bivalvia) from San Francisco Bay, California. Pac Sci 54:377-388

Okutani T (2000) Marine molluscs in Japan. Tokai University Press, Tokyo

Plotnikov VV (2007) Variation of ice conditions in the Far Eastern seas. In: Akulichev VA (ed) Far Eastern Seas of Russia (in 4 books). Book 1. Oceanological studies. 
Nauka, Moscow, p 154-183 (in Russian)

Robinson TB, Griffiths CL, Tonin A, Bloomer P, Hare MP (2005) Naturalized populations of oyster, Crassostrea gigas along the South African coast: distribution, abundance and population structure. J Shellfish Res 24: $443-450$

Roy K, Jablonski D, Valentine JW, Rosenberg G (1998) Marine latitudinal diversity gradients: Test of causal hypotheses. Proc Natl Acad Sci USA 95:3699-3702

Scarlato OA (1981) Bivalve mollusks of temperate waters of the northwestern Pacific. Nauka, Leningrad (in Russian)

Sokal RR, Rohlf FJ (1995) Biometry: the principles and practice of statistics in biological research, 3rd edn. W.H. Freeman, New York, NY

Starkov YV (ed) (2003) Nautical Charts of the Tatar Strait, Amurskiy Liman and the Laperouse Strait. CKF VMF, Saint Petersburg (in Russian)

Ushakov PV (1934) A contribution to the fauna of freshened waters of Amurskiy Liman and Sakhalin Gulf, Sea of Okhotsk. Bull Pac Comm Acad Sci USSR 3:39-40 (in Russian)

Ushakov PV (1940) Peculiarities of life near river mouths (estuaries). Priroda 5:41-49 (in Russian)

Ushakov PV (1948) The invertebrate fauna of Amurskiy Liman and the adjacent freshened areas of Sakhalin Gulf. In: Pavlovsky EN (ed) Memory of the academician Sergey Alekseevitch Zernov. USSR Academy of Sciences Press, Moscow-Leningrad, p 175-191 (in Russian)

Ushakov PV (1953) The fauna of the Sea of Okhotsk and its habitat conditions. USSR Academy of Sciences Press, Moscow (in Russian)

Editorial responsibility: Richard Osman,

Edgewater, Maryland, USA
Valentine JW, Jablonski D (2010) Origins of marine patterns of biodiversity: some correlates and applications. Paleontology 53:1203-1210

Wijnhoven S, Hummel H (2011) Patterns in macrozoobenthic assemblages indicate the state of the environment: insights from the Rhine-Meuse estuary. Mar Ecol Prog Ser 436:29-50

Wolanski E (2007) Estuarine ecohydrology. Elsevier, Amsterdam

Yavnov SV, Rakov VA (2002) Corbicula. TINRO-centre, Vladivostok (in Russian)

> Ysebaert T, Herman PMJ (2002) Spatial and temporal variation in benthic macrofauna and relationships with environmental variables in an estuarine, intertidal soft-sediment environment. Mar Ecol Prog Ser 244:105-124

Ysebaert T, Herman PMJ, Meire P, Craeymeersch J, Verbeek H, Heip CHR (2003) Large-scale spatial patterns in estuaries: estuarine macrobenthic communities in the Schelde estuary, NW Europe. Estuar Coast Shelf Sci 57: 335-355

Zhabin IA, Dubina VA, Nekrasov DA, Dudarev OV (2007) Structural features of the mixing zone between river and sea waters near Amur River mouth as detected by satellite and hydrological observations. Issledovanie Zemli iz Kosmosa 4:1-10 (in Russian with English Abstract)

Zhabin IA, Abrosimova AA, Dubina VA, Dudarev OV, Yurasov GI (2009) Structure and dynamics of water in the near mouth area of Amur River. In: Chelomin VP (ed) Condition of marine ecosystems influenced by the Amur River flow. Dalnauka, Vladivostok, p 11-34 (in Russian with English Abstract)

Submitted: February 15, 2011; Accepted: February 16, 2012 Proofs received from author(s): May 12, 2012 